Çukurova Üniversitesi Mühendislik Mimarlık Fakültesi Dergisi, 34(4), ss. 117-127, Aralık 2019

Çukurova University Journal of the Faculty of Engineering and Architecture, 34(4), pp. 117-127, December 2019

\title{
Bakır Flotasyonu Prosesinde, Köpük Görüntüleri ile \% Bakır Tenörü Arasındaki İlişkinin Görüntü Analiz Yöntemiyle Belirlenmesi
}

\section{Mehmet TÜRKMENOĞLU ${ }^{* 1}$, Ö. Faruk ÖZGÜVEN², Fatih Ş. ERKUŞ ${ }^{3}$, Ayșe ÖZGÜVEN ${ }^{4}$, Z. Funda TÜRKMENOĞLU ${ }^{1}$, O. Ozan VAROL ${ }^{1}$}

\author{
${ }^{I}$ Van Yüzüncü Yıl Üniversitesi, Mühendislik Fakültesi, Maden Mühendisliği Bölümü, Van \\ ${ }^{2}$ İnönü Üniversitesi, Mühendislik Fakültesi, Biyomedikal Mühendisliği Bölümü, Malatya \\ ${ }^{3}$ Van Yüzüncü Yll Üniversitesi, Ziraat Fakültesi, Biyosistem Mühendisliği Bölümü, Van \\ ${ }^{4}$ Van Yüzüncü Yıl Üniversitesi, Mühendislik Fakültesi, Çevre Mühendisliği Bölümü, Van
}

\author{
Geliş tarihi: 04.11.2019 Kabul tarihi: 20.12 .2019
}

\section{Öz}

Bu çalışmada, Siirt Madenköy flotasyon tesisinden temin edilen bakır cevherinin laboratuvar ölçekli flotasyonu esnasında elde edilen köpük görüntüleri ile bakır zenginleştirme tenörü arasındaki korelasyon belirlenmiștir. Sadece hava akıș hızı; 2 ile 8 1/dk arasında debimetre yardımı ile değiștirilmiș, diğer tüm flotasyon parametreleri tesis ile aynı tutulmuştur. Video kamera kullanılarak elde edilen köpük görüntüleri, MATLAB Havza Dönüşümü (MATLAB Watershed Transform) metoduyla işlenmiş ve hava kabarcıkları tanımlanmıştır. Kabarcık şekil ve büyüklük verileri, köpük görüntülerindeki kabarcık vadi sınırlarının tespiti ve bu sınırlarla görüntünün bölümlenmesi yoluyla elde edilmiştir. Bu çalışmada gerçekleştirilen 3 farklı flotasyon deney seti verileri kullanılarak flotasyon prosesinin otomasyonunda kullanılabilecek görüntü işleme tabanlı bulanık mantık çıkarım sistemi tasarımı yapılmıştır. Ölçülen ve hesaplanan bakır zenginleştirme tenörü arasındaki korelasyon katsayısı $r=0,96$ olarak hesaplanmıştır.

Anahtar Kelimeler: Flotasyon, Görüntü işleme, MATLAB, Bulanık mantık, Bakır cevheri

\section{Determination of the Relationship Between Foam Images with \% Copper Grade in Copper Flotation Process by Image Analysis Method}

\begin{abstract}
In this study, the correlation between the grade of copper enrichment and the foam images obtained during laboratory scale flotation of copper ore obtained from Siirt Madenköy flotation plant was determined. Only air flow rate was changed between 2 and $81 / \mathrm{min}$ with a flowmeter, all other flotation parameters were kept the same with the flotation plant. Foam images captured by a video camera were processed by MATLAB Watershed Transform method and air bubbles were defined. Bubble shape and size data were obtained by detecting and segmenting bubble watershed borders in foam images. In this study, image processing based fuzzy logic inference system that can be used in the automation of flotation process was designed using 3 different flotation experiment data sets. The correlation coefficient between measured and calculated grade of copper enrichment is $r=0,96$.
\end{abstract}

Keywords: Flotation, Image processing, MATLAB, Fuzzy logic, Cupper ore

*Sorumlu yazar (Corresponding author): Mehmet TÜRKMENOĞLU, mehmetturkmenoglu@yyu.edu.tr 


\section{GíRiş}

Flotasyon prosesinde; sıcaklık, karıştırma hızı, kimyasalların miktarı, $\mathrm{pH}$, hava miktarı ve flotasyon makinesindeki sıvı seviyesi gibi bazı konvansiyonel ölçümler mevcuttur. $\mathrm{Bu}$ ölçümler çeşitli ölçüm aletleri ile ölçülebilmekte ve kontrol edilebilmektedir. Ancak, flotasyon köpüğ̈̈ ölçümleri insan gözlemleriyle sınırlıdır. Şu anda işletilen birçok tesiste flotasyon prosesi kontrolü operatörlerin oluşan köpügü gözlemlemesi yoluyla sağlanmaktadır. Bu tesislerde flotasyon köpüğünün fiziksel ve sayısal metotlarla ölçülmesi ve karakterizasyonu mümkün olmadığından verim kayıpları yaşanmakta ve flotasyon prosesi performans1 operatörün deneyimine bağlı kalmaktadır. Ayrıca, flotasyonun başarı oranı kimyasal analiz sonuçları çıkıncaya kadar belirlenememektedir. Bu nedenle, kimyasal analiz sonuçlarına bağımlı olmayan daha hızlı başka kontrol metodlarının geliştirilmesi gerekmektedir. $\mathrm{Bu}$ çalışmada, bakır cevherinin flotasyon prosesi ile zenginleştirilmesi esnasında, köpük görüntüleri ve bakır zenginleştirme verimleri arasındaki ilişki, bulanık mantık metoduyla tespit edilmiştir.

Dijital görüntü işleme alanında görülen hızlı gelişmeler, operatörler tarafından yapılan gözlemlerin yerini alabilecek düzeye gelmiş; gerçek zamanlı, güvenilir ve tutarlı otomatik görüntü verilerinin kullanımını mümkün hale getirmiştir. Flotasyon köpüğü oluşumunu sağlayan hava kabarcıklarının büyüklügü ve şekli flotasyon süreci performansı hakkında önemli miktarda veri içermektedir. Görüntü işleme uygulamaları, endüstriyel alanda (Malzeme tane büyüklüğü analizi, gerçek zamanlı güvenlik uygulamaları, iki boyutlu cisimlerden grafik modeller için veri eldesi vb.) bir çok alanda yaygın olarak kullanılan [1] kendini ispatlamış bir kontrol tekniğidir.

Flotasyon prosesinin kontrolü ve optimizasyonu amacıyla kullanılan görüntü işleme teknikleri, fiziksel, statik ve dinamik özellikler olmak üzere başlıca üç temel kategoride sınıflandırılabilir [2]. Bu çalışmada ekonomik ve güvenilir şekilde eldesi mümkün olan köpük büyüklüğü verisi toplanmıştır.
Görüntü analiz sistemlerinin performansı, istatistik teknikleri [3], yapay sinir ağları [4] ve bulanık mantık [5] uygulamalarıyla entegre edilmiş, böylelikle verimi artırılmıştır. Literatürde mineral konsantrasyonlarının ve proses durumunun büyük ölçüde köpügüun rengi ve morfolojik özellikleriyle ilgili olduğu bildirilmiştir [6]. Köpük rengi, köpüğün taşıdığı mineral türü ve konsantrasyonu hakkında bilgi verebilmektedir. Köpügün prosesteki durumu özellikle köpük balonları büyüklüğüyle karakterize edilebilmekte ve böylece köpük miktarı, çarpışma ve tutunma verimi tespit edilebilmektedir. Balon büyüklüğü ve ayırma verimi arasındaki ilişkinin araştırıldığı çalışmalar kayda değer sonuçlar vermiştir. Hava balonları büyüklüğü ile ilgili çalışmalar; vadi bölümlemesi (segmentasyonu) [7-8], doku (tekstür) spektrumu [3] ve Dalgacık dönüşümü (Wavelet transformation) [9] şeklinde sinıflandırılabilir. Bu çalışmada ise, köpük fotoğrafları MATLAB Vadi Dönüşümü (MATLAB Watershed Transform) fonksiyonuyla analiz edilmiştir.

\section{2. ÖNCEKİ ÇALIŞMALAR}

Literatürde çok çeşitli sayıda cevherin farklı kimyasallar kullanılarak flotasyon yöntemiyle zenginleştirilmesinin çalışıldığ 1 birçok çalışma mevcuttur. Ancak, görüntü analiz sisteminin flotasyon ile birlikte kullanıldığı çok az çalışma vardır. $\mathrm{Bu}$ çalışmalardan bazıları aşağıda listelenmiştir.

Dijital kamera kullanılarak elde ettikleri köpük görüntüsü ile flotasyon performansı arasındaki ilişkiyi inceleyen Ekmekçi ve Şahin [10] (2006), Küre bakır cevheri üzerinde flotasyon deneyleri gerçekleştirmişlerdir. Deneylerde hava hızının, köpürtücü dozajının ve köpük yüksekliğinin flotasyon verimine olan etkisini incelemişlerdir. Hava hızının artmasıyla konsantrenin bakır veriminin arttığını ancak tenörünün düştüğünü, kabarcık hızının ve alanının ise arttığını bildirmişlerdir. Köpük yüksekliğinin artmasıyla birlikte bakır veriminin azaldığını ancak tenörünün arttığını, kabarcık hızı azalırken kabarcık alanının arttığını belirtmişlerdir. Ayrıca, köpürtücü miktarı arttırıldığında bakır veriminin arttığını, kabarcık 
alanı azalırken, kabarcık hızının arttığını bildirmişlerdir. Yazarlar, kabarcık alanı ile flotasyon performansı arasında saçınımlı bir ilişki olduğunu, bu nedenle görüntü analiz sistemi için bir kontrol parametresi olamayacağını, ancak kabarcık hızıyla flotasyon arasındaki uyumlu ilişki sayesinde flotasyon performansinin kontrol edilebileceğini ileri sürmüşlerdir.

Köpük büyüklüğünün flotasyon kontrolünde kullanımında karşılaşılan başlıca sorunlar Aldrich ve arkadaşları [11] tarafindan yüzeydeki görünür köpüklerin yüzeyaltı köpükleri temsil edememesi ve kullanılan segmentasyon algoritmalarının büyük köpükleri daha büyük, küçük köpükleri daha küçük boyutlandırdığını bildirmiştir. $\mathrm{Bu}$ çalışmada flotasyon işlemi sırasında elde edilen gerçek zamanlı görüntülerdeki köpük büyüklükleri bakır kazanım verimleri ile bulanık mantık kurallarıyla ifade edilerek optimum köpük büyüklüğü tahmininin yapılması sağlanmıştır.

Miskovic [12] yaptığı doktora çalışmasında, pilot ölçekli bir flotasyon devresinde gerçekleştirdiği hidrodinamik ve metalurjik testler ile kabarcık boyutunu belirlemeye çalışmıştır. Ayrıca flotasyon başlığının (rotor) tasarımının kabarcık oluşumu üzerindeki etkisini araştırmıştır. Deneyler sonucunda, görüntü analiz tekniği ile kabarcık sayı ve büyüklüğünü modelleyen iki farklı yöntemi karşılaştırmıştır ve havalandırma hızının köpük oluşumu üzerinde önemli bir etkiye sahip olduğunu ileri sürmüştür.

Altaş [13], "Sondaj köpükleri özniteliklerinin görüntü işleme teknikleri ile çıkarımı ve yapay sinir ağları kullanarak veri analizi” başlıklı yüksek lisans tezinde, köpüklerin görsel özniteliklerini görüntü işleme metotlarıyla algılayacak ve YSA kullanılarak veri analizi yapabilecek bir model geliştirmeyi amaçlamıştır. Sınırlarını belirlediği köpüklerin yarıçap, alan, çevre gibi boyut ve biçim özelliklerini çıkarmış, kimyasal veriler ile birleştirerek YSA (Yapay Sinir Ağları) kullanarak veri analizi yapmıştır. Yaptığı incelemeler sonucunda görüntü işleme metodu ile elde edilen köpük verilerinin YSA ile analizinin mümkün olduğunu göstermiştir.

\section{MATERYAL VE METOT}

\subsection{Materyal}

Çalışma Van Yüzüncü Yıl Üniversitesi, Maden Mühendisliği Bölümü Laboratuvarındaki 1 lt hacimli, havalandırma ve karıştırma ünitesi içeren Denver D12 tipi flotasyon hücresinde, manometre ve debimetre ile hava akımı kontrol edilerek, kesikli flotasyon deneyleriyle gerçekleştirilmiştir.

Köpük görüntülerinin alımı, Logitech C920 marka webcam kullanılarak MATLAB programının gerçek zamanlı görüntü alma ve işleme fonksiyonları kullanılarak gerçekleştirilmiştir. Şekil 1'de flotasyon makinasına teşkil edilen kamera, 25W gücünde 1şık kaynağ1 ve görüntülerin işlendiği bilgisayar görülmektedir. Görüntü işlemede kullanılan en iyi görüntü, köpüğe dik açıyla konumlandırılan kamerayla ve tek bir 1 şı kaynağı kullanılarak elde edilmiştir. İşlenen görüntülerden elde edilen verilerle oluşturulan model, Matlab 2010 programının 'fuzzy' editörüyle oluşturulmuştur.

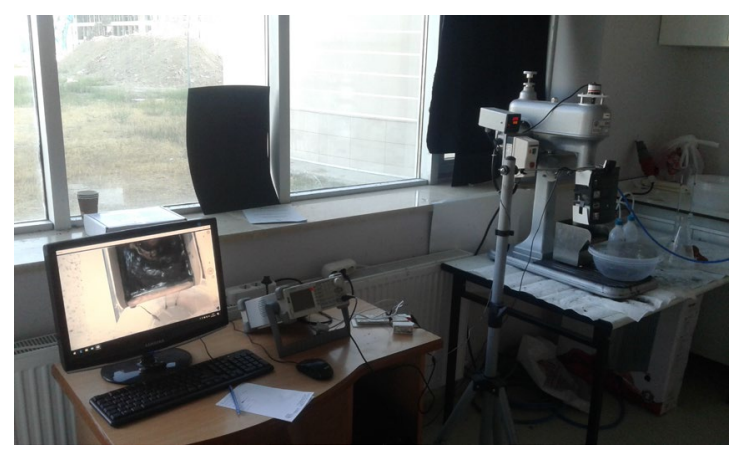

Şekil 1. Çalışmada kullanılan flotasyon makinesi ve kamera sistemi

\subsection{Metot}

Bakır cevheri laboratuvarda flotasyon prosesi ile zenginleştirilirken; bakır örneklerinin alındığg Siirt Madenköy flotasyon tesisinde kullanılan kimyasallar (Aerophine 3418 A, MIBC, Sodyum Silikat, $\left.\mathrm{Ca}(\mathrm{OH})_{2}\right)$ ile diğer faktörler $(\mathrm{pH}$, katı-sıvı oranı, cevher boyutu) tesis değerleriyle aynı tutulmuş, sadece kompresöre bağlanan hava 
Bakır Flotasyonu Prosesinde, Köpük Görüntüleri ile \% Bakır Tenörü Arasındaki Illişkinin Görüntü Analiz Yöntemiyle Belirlenmesi

debimetre ile akış hızı; 2-8 1/dk arasında olacak şekilde değiştirilmiştir.

Köpük boyutunun belirlenmesi amaciyla flotasyon işlemi sırasında gerçek zamanlı video görüntülerinden 10 sn aralıklarla görüntü alınarak havza dönüşümü uygulanmıştır. $\mathrm{Bu}$ dönüşümde köpük görüntüsünün yoğun olduğu alanlar 'dağ', yoğun olmadığı alanlar 'vadi' olarak tanımlanarak vadiler tespit edilir. Görüntü işleme yönteminin izahı amacıyla alınan bir görüntüye uygulanan işlemler aşağıda sırasıyla anlatılmıştır. Çalışmada kullanılan flotasyon görüntülerinden biri Şekil 2'de verilmiştir.

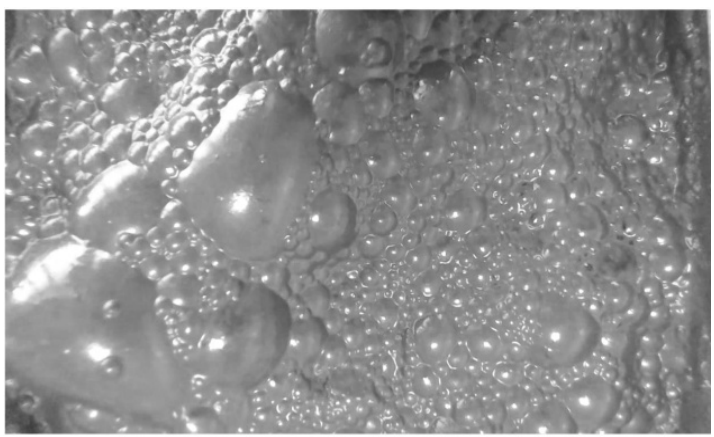

Şekil 2. Çalışmada kullanılan flotasyon görüntüsü

Havza dönüşümü işleminde vadi sayısını minimize etmek için ilgilenilen boyuttaki köpüklerin kontrastları maksimize edilir. Kontrast artırımı için kullanılan yaygın bir yöntem top-hat ve bottom-hat dönüşümlerinin birlikte kullanımıdır. Şekil 3'de ve Şekil 4'de, orijinal görüntüye imtophat ve imbothat fonksiyonlariyla top-hat ve bottom-hat dönüşümleri uygulanmış görüntü sunulmuştur.

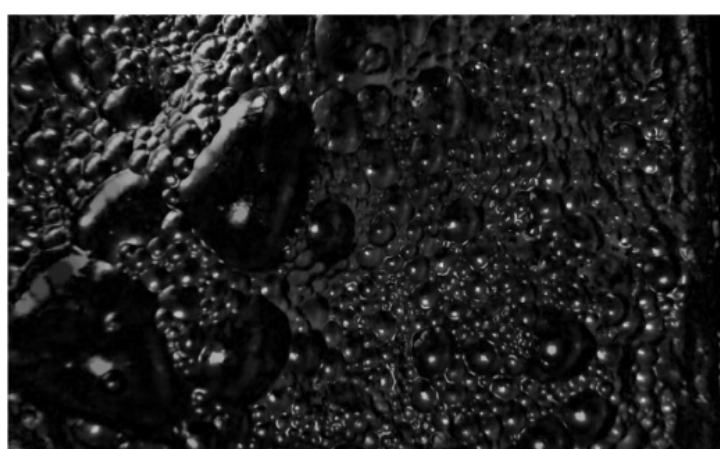

Şekil 3.Flotasyon görüntüsünde top-hat dönüşümü

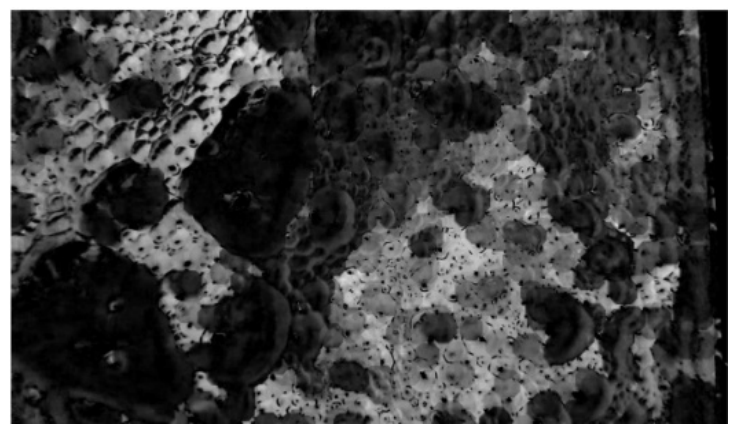

Şekil 4. Görüntüde bottom-hat dönüşümü

Şekil 5'de, elde edilen artırılmış tepe-çukur karşıtlığının hedeflenen yoğunluk vadilerine dönüştürebilmesi amaciyla incomplement fonksiyonu kullanılır.

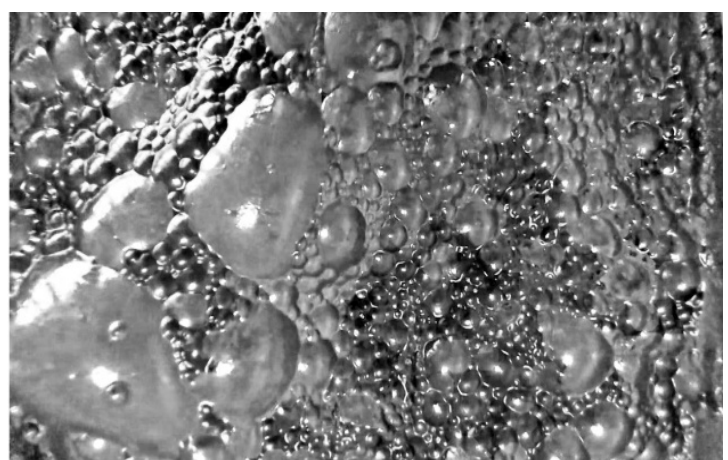

Şekil 5. Artırılmış tepe-çukur karşıtlığı

Şekil 6'da sunulan yoğunluk vadilerinin tümü imextendedmin fonksiyonuyla belirli bir eşiğin altında tespit edilir. Bu fonksiyonun çıktıları, 0 ve 1 kodlanmış piksellerden oluşan ikili görüntü (binary image) şeklindedir.

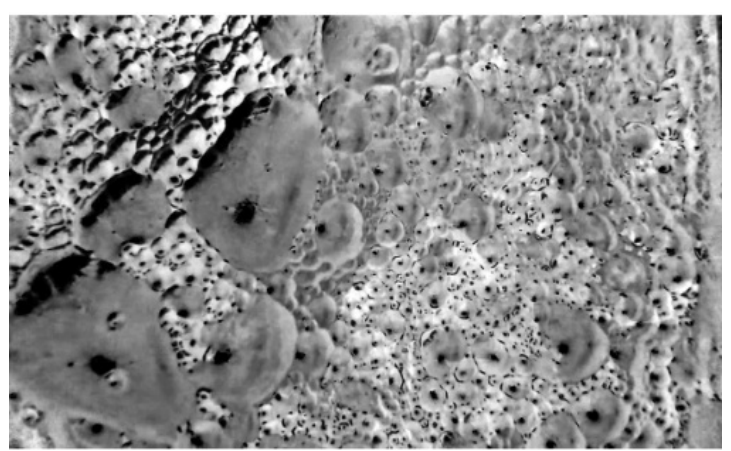

Şekil 6. Yoğunluk vadilerinin oluşturulması 
$\mathrm{Bu}$ işlemden sonra, imextendedmin fonksiyonu görüntüsünde vadilerin büyüklüğü yerine konumu önemlidir. Imimposemin fonksiyonu ile görüntüde sadece imextendedmin fonksiyonuyla tespit edilen vadilerin bulunması sağlanır. $\mathrm{Bu}$ fonksiyonla ayrıca uint8 görüntülerinin ulaşabileceği en derin vadi değeri olan sıfır değerine ulaşması mümkün olur. Minumum değer uygulanan tüm bölgeler havza dönüşümü tarafından tespit edebilecektir. Minumum eşiğe genişletilmiş vadiler Şekil 7'de ve minumum değer uygulanmış görüntü Şekil 8'de verilmiştir.

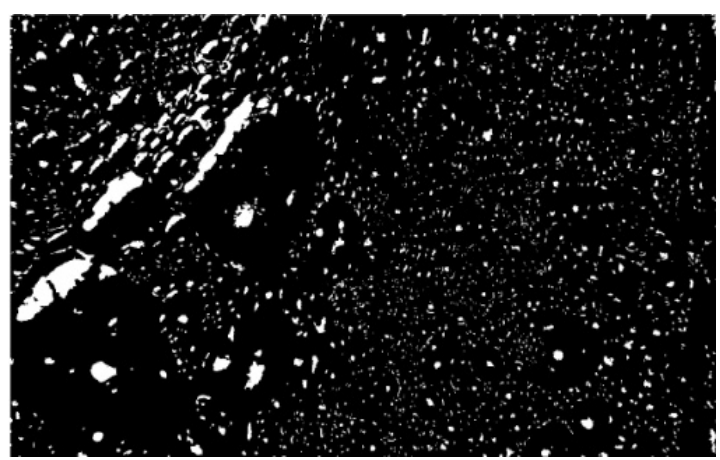

Şekil 7. Minumum eşiğe genişletilmiş vadiler

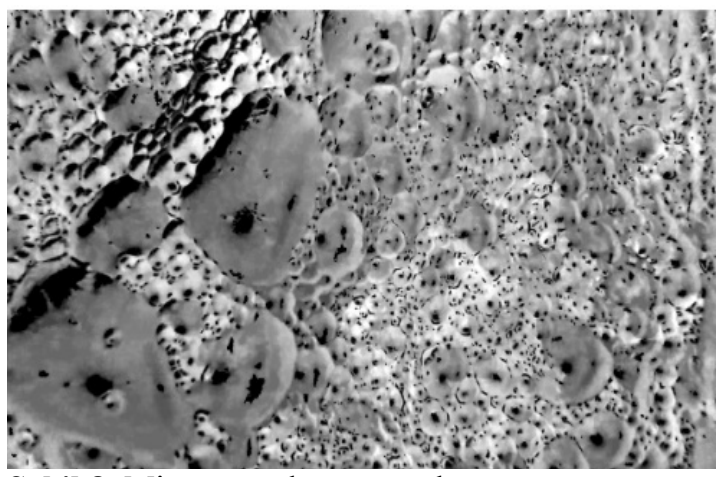

Şekil 8. Minumum değer uygulanmış görüntü

Minimum değer uygulanmış görüntünün havza bölümlemesi watershed fonksiyonuyla sağlanır. $\mathrm{Bu}$ fonksiyon, görüntüyü vadi bölgeleriyle ilişkilendirilmiş negatif olmayan sayılar içeren matrise dönüştürür. Havza alanına girmeyen piksellere sıfır piksel değeri verilir. Şekil 9'da etiket matrisi, label2rgb fonksiyonu kullanilarak görüntü olarak gösterilmiştir.

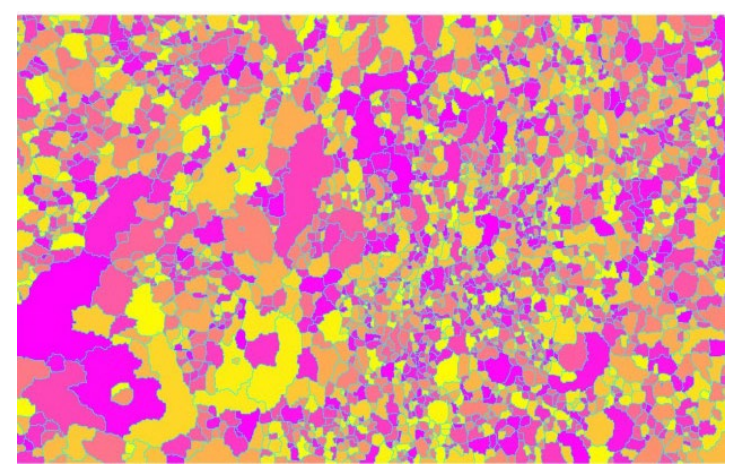

Şekil 9. Havza bölümlemesi

Etiket matrisinin özellikleri regionprops fonksiyonuyla çıkarılabilir. $\mathrm{Bu}$ fonksiyonla parçacık (köpük) alanları ve yönleri hesaplanır. Şekil 10'da köpük alanı ve yönü verilmiştir.

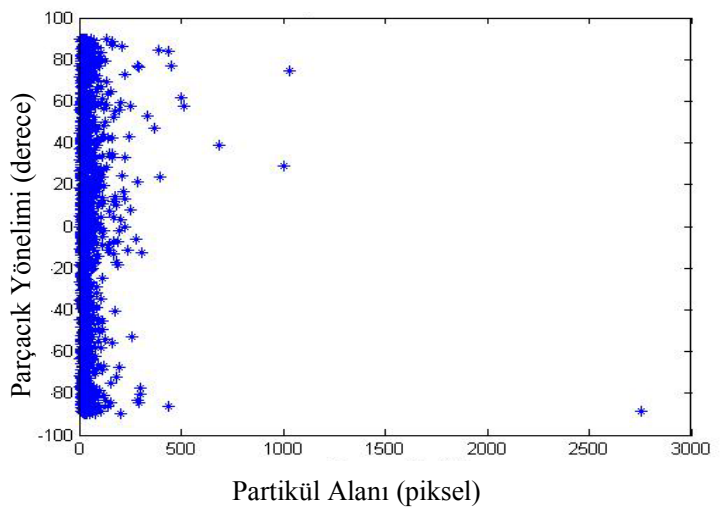

Şekil 10. Parçacık yöneliminin alanla ilişkisi

Elde edilen "köpük alanı (area)" değerleri, "köpük sayısı" ve flotasyonda hedeflenen büyüklükteki köpüğün oluşturduğu "alan ortalaması" değerleri kullanılarak, bulanık mantık modeli oluşturulmuştur. Şekil 2'deki görüntü için köpük alanı, köpük sayısı ve köpük alanı ortalama değerleri Çizelge 1 'de sunulmuştur.

Çizelge 1. Bulanık mantık modelinin oluşturulmasında kullanılan giriş verileri

\begin{tabular}{|c|c|c|}
\hline $\begin{array}{c}\text { Toplam } \\
\text { köpük alanı }\end{array}$ & $\begin{array}{c}\text { Köpük } \\
\text { sayısı }\end{array}$ & $\begin{array}{c}\text { Ortalama } \\
\text { köpük alanı }\end{array}$ \\
\hline 8050 piksel & 1850 adet & 2810 piksel \\
\hline
\end{tabular}




\section{BULGULAR VE TARTIŞMA}

Flotasyon, kaotik doğası ve ölçümlerinde kullanılan teknolojilerin yetersizliği nedenleriyle maden endüstrisinde modellenmesi ve kontrolü zor süreçlerden biridir. Flotasyon tesislerindeki işletme koşulları büyük ölçüde flotasyon köpüğü görünümüyle ilişkilendirilmektedir [11]. $\mathrm{Bu}$ çalışmada köpük boyutu tahmin yaklaşımının basit ve güvenilir şekilde uygulanabildiği gösterilmiştir. Çalışmada bakır flotasyonu sürecine uygulanan gerçek zamanlı bir görüntü analiz sistemi sunulmaktadır. Görüntü analiz sisteminde köpük boyutunun verimli bir şekilde tahmini yapılmıştır.

Flotasyon deney koşulları Çizelge 2'de verilmiştir. Hava akış hızı; 2-8 1/dk arasında olacak şekilde ayarlandiktan sonra; elde edilen konsantrelerin ve atıkların bakır tenörleri belirlenmiştir. Flotasyon deneyleri sonucunda elde edilen konsantre ve atıklara ait bakır yüzdeleri Çizelge 3 'de verilmiştir.

Çizelge 2. Flotasyon deney koşulları

\begin{tabular}{|l|c|c|}
\hline Kollektör & Aerophine 3418A & $50 \mathrm{~g} / \mathrm{t}$ \\
\hline Köpürtücü & MIBC & $20 \mathrm{~g} / \mathrm{t}$ \\
\hline Bastırıc1 & Sodyum Silikat & $45 \mathrm{~g} / \mathrm{t}$ \\
\hline pH düzenleyici & Sönmüş kireç & $8 \mathrm{~kg} / \mathrm{t}$ \\
\hline Katı/sıv1 oranı & $\% 30$ & Sabit \\
\hline $\mathrm{pH}$ & $11,8-12$ & Sabit \\
\hline Karıştırma hızı & $1250 \mathrm{~d} / \mathrm{d}$ & Sabit \\
\hline Karıştırma süresi & $3 \mathrm{~d}$ & Sabit \\
\hline $\begin{array}{l}\text { Köpük alma } \\
\text { süresi }\end{array}$ & $3 \mathrm{~d}$ & Sabit \\
\hline Numune boyutu & $-75 \mu$ & Sabit \\
\hline
\end{tabular}

Çizelge 3. Flotasyon deneylerinde elde edilen konsantre ve atıkların bakır yüzdeleri

\begin{tabular}{|c|c|c|}
\hline & $\begin{array}{c}\text { Konsantre } \\
(\% \mathbf{C u})\end{array}$ & $\begin{array}{c}\text { Atık } \\
(\% \mathbf{C u})\end{array}$ \\
\hline $\mathbf{2} \mathbf{~} \mathbf{~ / d k}$ & 6,60 & 0,99 \\
\hline $\mathbf{3} \mathbf{~} \mathbf{d} \mathbf{d k}$ & 7,84 & 0,86 \\
\hline $\mathbf{4} \mathbf{~} \mathbf{d} \mathbf{d k}$ & 7,78 & 0,89 \\
\hline $\mathbf{5} \mathbf{~} \mathbf{d} \mathbf{d k}$ & 7,71 & 0,90 \\
\hline $\mathbf{6} \mathbf{~} \mathbf{d} \mathbf{d k}$ & 7,52 & 0,90 \\
\hline $\mathbf{7} \mathbf{~} \mathbf{d} \mathbf{d k}$ & 7,38 & 0,92 \\
\hline $\mathbf{8} \mathbf{~} \mathbf{d} \mathbf{d k}$ & 7,05 & 0,93 \\
\hline
\end{tabular}

Çalışma süresince 3 defa tekrarlanan ve akış hızının 2, 3, 4, 5, 6, 7, 8 1/d olarak değiştirildiği deney setlerinden online olarak elde edilebilen veri setleri ortalaması flotasyon süresinin birinci, ikinci ve üçüncü dakikaları için Çizelge 4'te sunulmuştur.

Çizelge 4. Bulanık mantık modelinin oluşturulmasında kullanılan giriş veri setleri

\begin{tabular}{|c|c|c|c|}
\hline & $\begin{array}{c}\text { Toplam } \\
\text { köpük alanı } \\
\text { (piksel) }\end{array}$ & $\begin{array}{c}\text { Köpük } \\
\text { sayısı } \\
\text { (adet) }\end{array}$ & $\begin{array}{c}\text { Ortalama } \\
\text { köpük alanı } \\
\text { (piksel) }\end{array}$ \\
\hline S2-1 & 2693 & 533 & 1385 \\
\hline S2-2 & 8284 & 247 & 2238 \\
\hline S2-3 & 11267 & 194 & 2657 \\
\hline S3-1 & 3915 & 626 & 1515 \\
\hline S3-2 & 15523 & 276 & 2797 \\
\hline S3-3 & 19305 & 256 & 2794 \\
\hline S4-1 & 5563 & 688 & 2437 \\
\hline S4-2 & 13829 & 250 & 2531 \\
\hline S4-3 & 12120 & 193 & 2272 \\
\hline S5-1 & 16666 & 311 & 1921 \\
\hline S5-2 & 3611 & 395 & 2425 \\
\hline S5-3 & 4015 & 355 & 2605 \\
\hline S6-1 & 14342 & 410 & 2071 \\
\hline S6-2 & 2665 & 434 & 1474 \\
\hline S6-3 & 2190 & 448 & 1338 \\
\hline S7-1 & 8819 & 418 & 1915 \\
\hline S7-2 & 2885 & 515 & 1291 \\
\hline S7-3 & 1924 & 701 & 1358 \\
\hline S8-1 & 10996 & 416 & 2605 \\
\hline S8-2 & 6007 & 605 & 1824 \\
\hline S8-3 & 2817 & 640 & 1466 \\
\hline
\end{tabular}

Bulanık sistemlerde genellikle dört temel aşama bulunur. Bunlar; üyelik fonksiyonları (bulanıklaştırma), bulanık kural tabanı, durulaştırma ve bulanık sistem çıktılarıdır. Bulanık çıkarım motoru, bulanık kural tabanındaki tüm bulanık kuralları değerlendirerek giriş verilerini ilgili çıkış verilerine dönüştürür.

$\mathrm{Bu}$ çalışmada giriş parametreleri, toplam köpük alanı "area", köpük sayısı "Sayi" ve ortalama köpük alanı "ortalama" ve çıkış parametresi, \% bakır zenginleştirme verimi "verim" parametrelerinden oluşan üyelik fonksiyonları ve 
giriş-çıkış ilişkileri tasarımı Şekil 11'de sunulmuştur. Şekil 12 ve 13 'de ise en uygun yazılım performansı sağlamak amacıyla giriş ve çıkıș değişkenleri için seçilen üçgen ve yamuk fonksiyonları ile tanımlanan üyelik fonksiyonları gösterilmiştir.

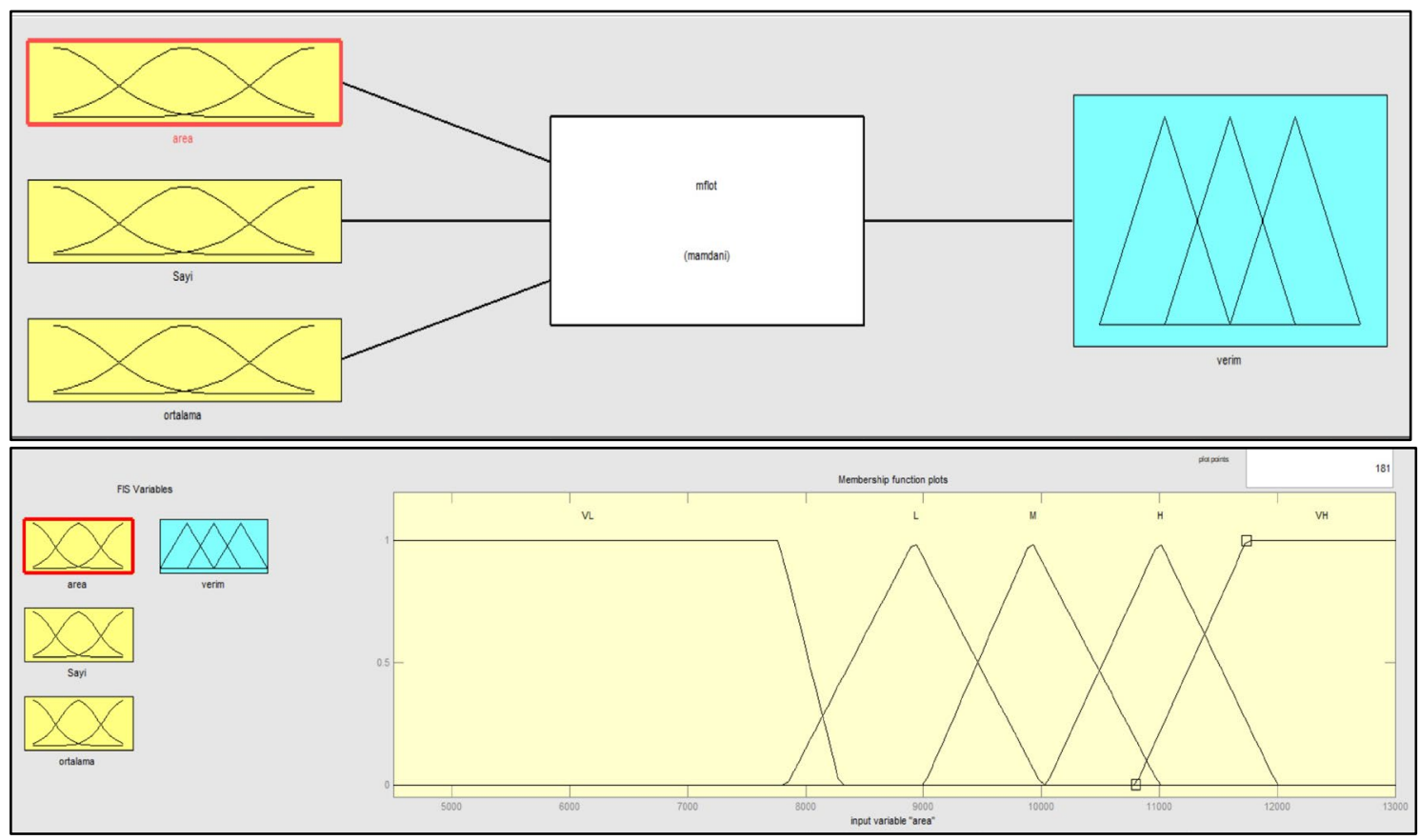

Şekil 11. Giriş ve çıkış parametreleri
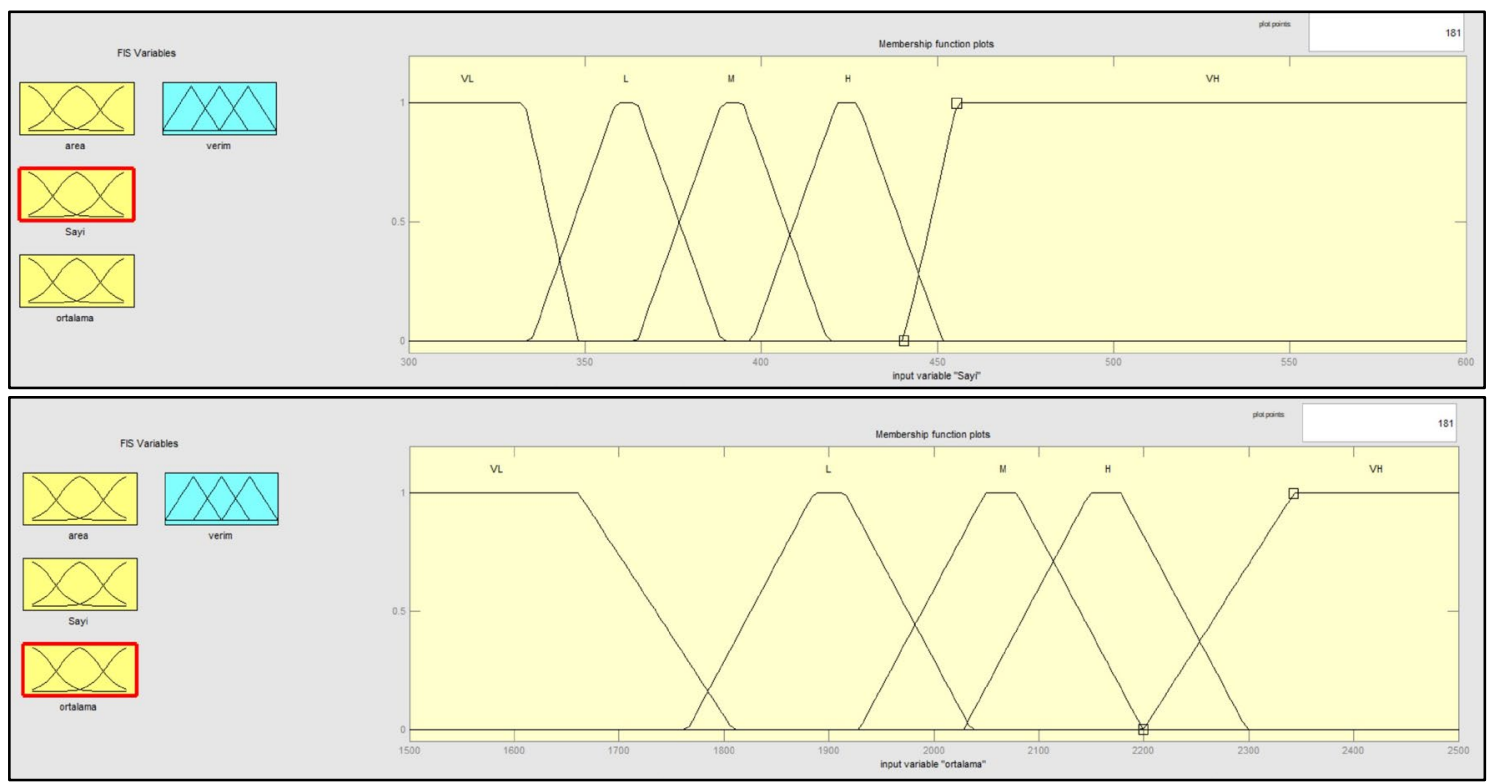

Şekil 12. Giriş parametreleri üyelik fonksiyonları 
Bakır Flotasyonu Prosesinde, Köpük Görüntüleri ile \% Bakır Tenörü Arasındaki İlişkinin Görüntü Analiz Yöntemiyle Belirlenmesi

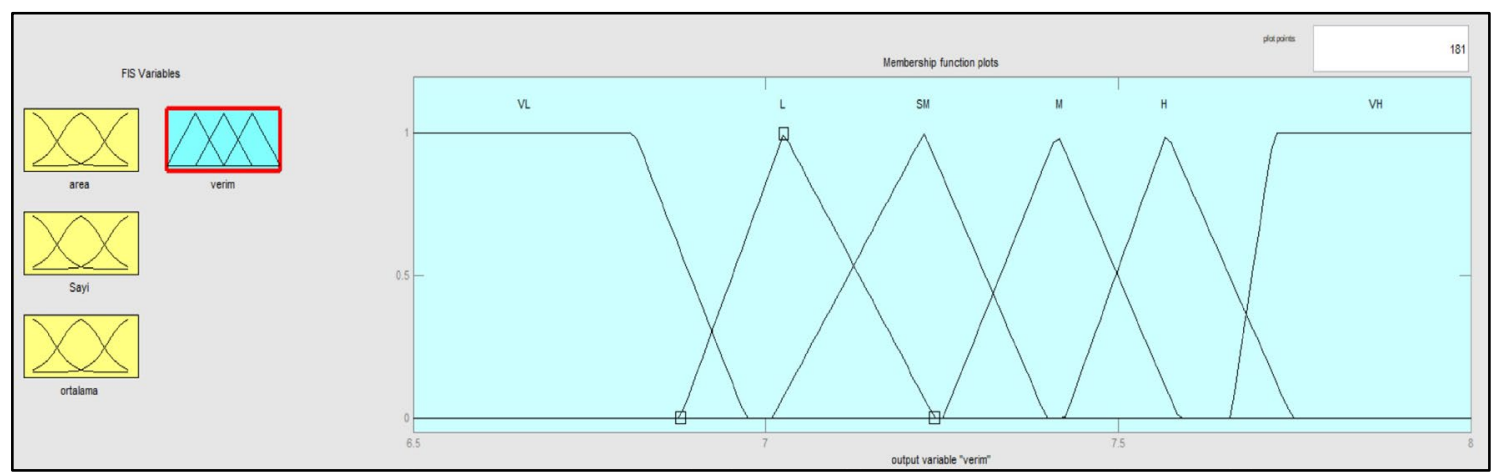

Şekil 13. Çıkış parametresi üyelik fonksiyonu

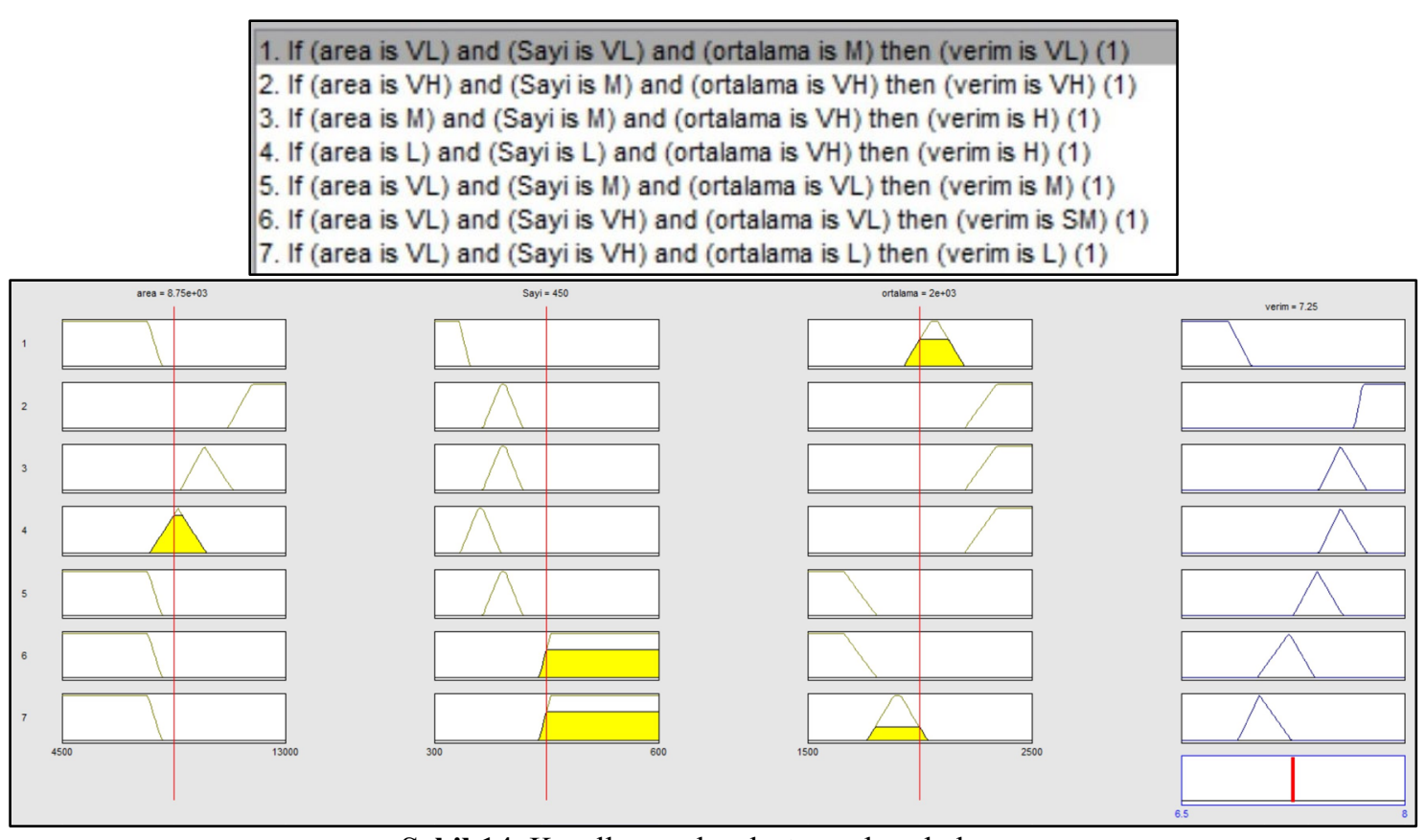

Şekil 14. Kurallar ve durulaştırma kural ekranı

Durulaştırma basamağında uygulanan kurallar ise Şekil 14'teki kural gösterim ekranında verilmiştir.

Bulanık kural tabanlı model tasarımı, deneysel veriler kullanılarak "Eğer-İse" kuralları ile gerçekleştirilmiştir. Bu çalışmada bulanık setleri "çok düşük, düşük, küçük orta, orta, yüksek ve çok yüksek" dil terimleri kullanılarak oluşturulmuştur. Bulanık kurallar oluşturulurken giriş ve çıkış verileri arasındaki muhtemel tüm ilişkiler model tasarımında dikkate alınmıştır. Üyelik fonksiyonları tanımlandıktan sonra kural tabanı oluşturulmuştur. Kural tabanındaki kurallar, "Eğer $\mathrm{X}=\mathrm{A}$ ve $\mathrm{Y}=\mathrm{B}$ İse, $\mathrm{Z}=\mathrm{C}$ 'dir" formatında tanımlanmıştır. Bu çalışmada "Eğer alan Çok Yüksek ve Sayı Çok Yüksek ve Ortalama Orta İse; Verim Çok Düşük'tür" gibi farklı dil terimleriyle tanımlanan 7 kural kullanılmıştır. Modelin geçerli kılınması için deneysel giriş verileri kullanılarak çıkış parametrelerinin tahmin edilmesi sağlanmıştır.

Şekil 15'te giriş verileriyle verim yüzdesi çıkış verilerinin model yüzey tahminleri verilmiştir. 
$\mathrm{Bu}$ çalışmada gerçekleştirilen 3 farklı flotasyon deney seti verileri kullanılarak bulanık mantık çıkarım sistemi ile flotasyon sisteminin görüntü işleme yöntemiyle modellenmesi sağlanmıştır. Flotasyon deneylerinde ölçülen \% bakır tenörü sonuçlarıyla model ile tahmin edilen değerler Çizelge 5'te sunulmuştur. Ölçülen ve hesaplanan $\%$ bakır zenginleştirme tenörü arasındaki korelasyon katsayısı $r=0,96$ hesaplanmıştır.

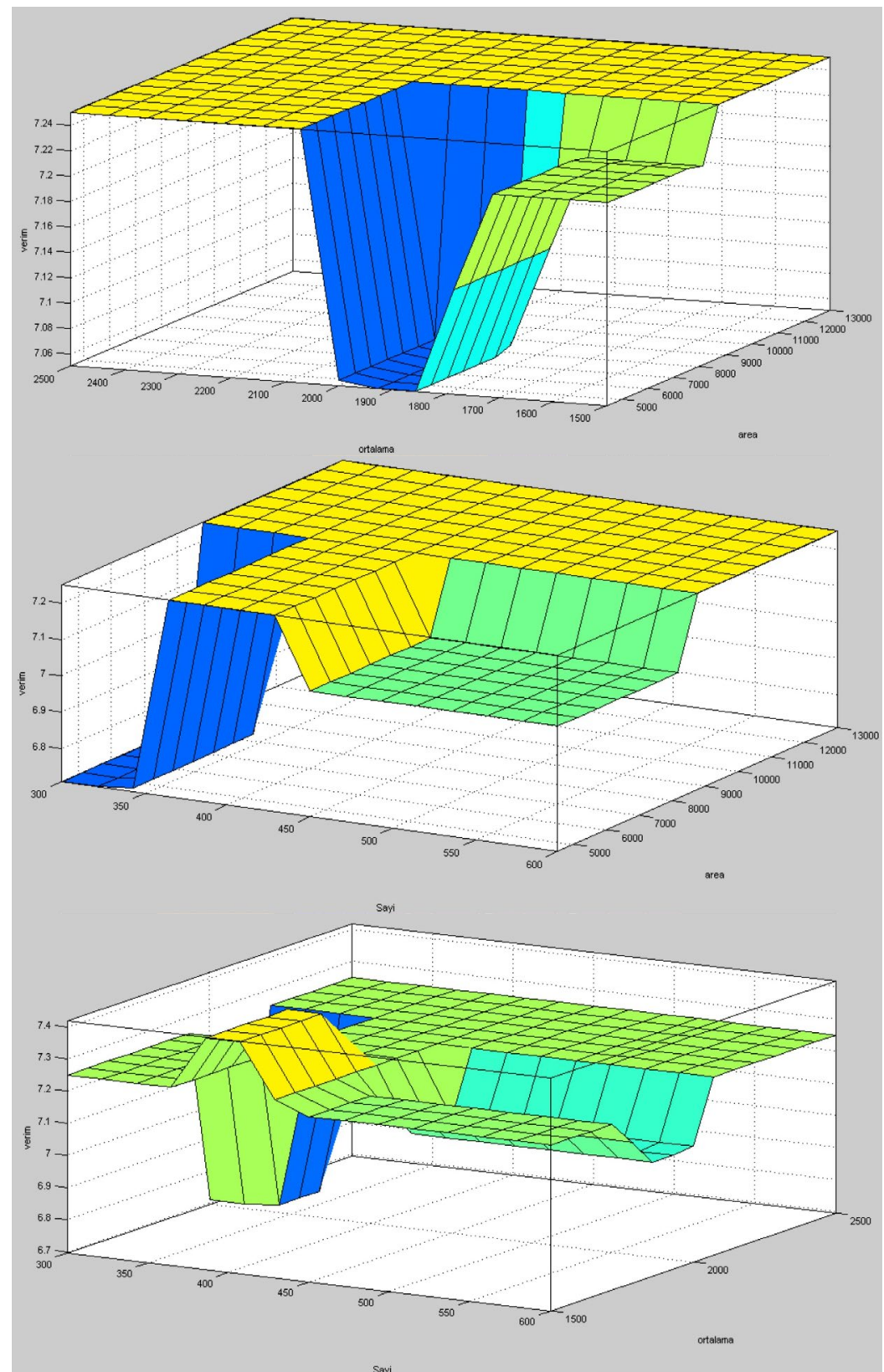

Şekil 15. Bulanık mantık çıkarım modelinin verim tahminlerinin Ağırlık merkezini bulma, Sayı-area ve Sayı-ortalama parametreleri için yüzey gösterimi 
Çizelge 5. Flotasyon deneylerinde ölçülen \% bakır tenörleri ve model ile tahmin edilen bakır tenörleri

\begin{tabular}{|c|c|c|}
\hline $\begin{array}{l}\text { Hava } \\
\text { Debisi }\end{array}$ & $\begin{array}{l}\text { AAS ile ölçülen } \\
\text { \% bakır tenörü }\end{array}$ & $\begin{array}{c}\text { Bulanık mantık ile } \\
\text { tahmin edilen \% } \\
\text { bakır tenörü }\end{array}$ \\
\hline $2 \mathrm{l} / \mathrm{dk}$ & 6,60 & 6,70 \\
\hline $3 \mathrm{l} / \mathrm{dk}$ & 7,84 & 7,85 \\
\hline $4 \mathrm{l} / \mathrm{dk}$ & 7,78 & 7,58 \\
\hline $5 \mathrm{l} / \mathrm{dk}$ & 7,71 & 7,58 \\
\hline $6 \mathrm{l} / \mathrm{dk}$ & 7,52 & 7,25 \\
\hline $7 \mathrm{l} / \mathrm{dk}$ & 7,38 & 7,21 \\
\hline $8 \mathrm{l} / \mathrm{dk}$ & 7,05 & 7,05 \\
\hline
\end{tabular}

\section{TARTIŞMA VE SONUÇ}

$\mathrm{Bu}$ çalışma sonucunda elde edilen sonuçlar ve öneriler aşağıda listelenmiştir;

- Bakır içeriği \%2,97 olan orijinal numune üzerinde gerçekleştirilen kaba flotasyon deneyleri sonucunda, en yüksek tenörde bakır zenginleştirme $31 / d k$ hava akıs hızında elde edilen konsantrede gerçekleştirilmiştir.

- Kaba flotasyon deneyleri sonucunda elde edilen (3 1/dk hava akış hızı ile elde edilen) konsantrede kalkopirit miktarı artarken atıkta bu miktar azalmıştır. Kimyasal analiz sonuçlarına göre konsantrenin bakır tenörü $\% 7,84$ iken bu oran atıkta $\% 0,86$ olarak belirlenmiştir.

- 1 1/dk hava akış hızında sağlıklı veriler elde edilememiştir. Hava akış hızı 3 1/dk'dan sonra artırıldığında konsantredeki bakır tenöründe az da olsa düşüşler meydana gelmiştir.

- Bu çalışmada gerçekleştirilen 3 farklı flotasyon deney seti verileri kullanılarak bulanık mantık çıkarım sistemi ile flotasyon sisteminin görüntü işleme yöntemiyle modellenmesi sağlanmıştır. Flotasyon deneylerinde ölçülen \% bakır tenörü sonuçlarıyla model ile tahmin edilen değerler birbirine oldukça yakın çıkmıștır. Ölçülen ve hesaplanan $\%$ bakır zenginleştirme tenörleri arasındaki korelasyon katsayısı $r=0,96$ olarak hesaplanmıştır.

- Çalışma sonucunda flotasyon prosesi hava akış hızınının optimum seviyede ișletimini mümkün kılan görüntü işleme tabanlı bulanık mantık tahmin modeli geliştirilmiştir. $\mathrm{Bu}$ modelin flotasyon proseslerinin otomasyonunda kullanılabilecek faydalı bir araç olduğu online veri analizi ve sistem simülasyonu yapılarak gösterilmiştir.

\section{TEŞEKKÜR}

Yazarlar, bu çalışmayı 2015-MİM-B090 proje numarası ile destekleyen Van Yüzüncü Y1l Üniversitesi Bilimsel Araştırma Projeleri Koordinasyon Birimine değerli katkılarından dolayı teşekkürlerini sunarlar.

\section{KAYNAKLAR}

1. Karakoç M., 2012. Görüntü İşleme Teknolojileri ve Uygulamaları. Ege Üniversitesi Fen Bilimleri Enstitüsü Bilgisayar Mühendisliği Anabilim Dalı Ders Notları, İzmir.

2. Shean B.J., Cilliers, J.J., 2011. A Review of Froth Flotation Control. International Journal of Mineral Processing, 100(3), 57-71.

3. Nguyen K.K., Thornton A.J., 1995. The Application of Texture-based Image Analysis Techniques in Froth Flotation. In: Conference Proceedings DICTA-95. Digital Image Computing: Techniques and Applications, Australian Pattern Recognition Society.

4. Moolman, D.W., Aldrich, C., Van Deventer, J.S.J., Bradshaw, D.J., 1995. The Interpretation of Flotation Froth Surfaces By Using Digital Image Analysis and Neural Networks. Chemical Engineering Science 50(22), 3501-3523.

5. Chuk, O.D., Ciribeni, V., Gutierrez, L.V., 2005. Froth Collapse in Column Flotation: a Prevention Method Using Froth Density Estimation and Fuzzy Expert Systems. Minerals Engineering 18(5), 495-504.

6. Moolman, D.W., Eksteen, J.J., Aldrich, C., van Deventer, J.S.J., 1996. The Significance of 
Flotation Froth Appearance for Machine Vision Control. International Journal of Mineral Processing 48(3-4), 135-158.

7. Sadr-kazemi, N., Cilliers, J., 1997. An Image Processing Algorithm for Measurement of Flotation Froth Bubble Size and Shape Distributions. Minerals Engineering 10(10), 1075-1083.

8. Bonifazi, G., Serranti, S., Volpe, F., Zuco, R., 2001. Characterisation of Flotation Froth Colour and Structure by Machine Vision. Computers \& Geosciences 27(9), 1111-1117.

9. Liu, J.J., MacGregor, J.F., Duchesne, C., Bartolacci, G., 2005. Flotation Froth Monitoring Using Multiresolutional Multivariate Image Analysis. Minerals Engineering 18, 65-76.

10. Ekmekçi, Z., Şahin, A.N., 2006. Köpük Görüntüsü ve Flotasyon Performans1 Arasındaki İlişkinin Görüntü Analiz Sistemi ile İncelenmesi. Madencilik Dergisi, 45(2), 27-38.

11. Aldrich, C., Moolman, D.W., Gouws, F.S., Schmitz, G.P.J., 1997. Machine Learning Strategies for Control of Flotation Plants. Control Engineering Practice 5(2), 263-269.

12. Miskoviç, S., 2011. An Investigation of the Gas Dispersion Properties of Mechanical Flotation Cells: An in-situ Approach. Doctor of Philosophy, Mining and Minerals Engineering, Virginia Polytechnic Institute, State Uni., 183.

13. Altaş, V.M., 2007. Sondaj Köpükleri Özniteliklerinin Görüntü İşleme Teknikleri ile Çıkarımı ve Yapay Sinir Ağları Kullanarak Veri Analizi. TOBB Ekonomi ve Teknoloji Üniversitesi Fen Bilimleri Enstitüsü Yüksek Lisans Tezi, 109. 
